\title{
Lymphatic blockage and severe edema in dermatomyositis: lessons from this case and others
}

\author{
Dean Sherzai ${ }^{1}$, Rajiv Rao $^{2}$, Chau Nguyen ${ }^{3}$, Eloy Schulz ${ }^{4}$, Ayesha Sherzai $^{1}$ \\ 1. Department of Neurology, Loma Linda University, USA. 2. School of Medicine, Loma Linda University, USA. \\ 3. Department of Rheumatology, Loma Linda University, USA. 4. Department of Nuclear Medicine, Loma Linda University, \\ USA.
}

Correspondence: Dean Sherzai. Address: 11175 Campus Street, CP-11108, Loma Linda, CA 92354, USA. E-mail: DSherzai@llu.edu

Received: January 15, 2014

DOI : $10.5430 /$ crcp.v1n2p12
Accepted: March 16, $2014 \quad$ Online Published: March 21, 2014

URL: http://dx.doi.org/10.5430/crcp.v1n2p12

\section{Abstract}

Generalized subcutaneous edema is a rare presentation of dermatomyositis. Here, we describe the case of a 57 year-old Hispanic female who presented with dermatomyositis and generalized edema. This case represents the first report of decreased lymphatic drainage, investigated using lymphoscintigraphy in dermatomyositis. Upon reviewing the literature regarding dermatomyositis cases with generalized edema, we found that treatment response and imaging modalities such as lymphoscintigraphy may provide insight into underlying pathophysiology and possible disease management.

\section{Key words}

Dermatomyositis, Autoimmune diseases, Inflammation

\section{I ntroduction}

Dermatomyositis (DM) is a rare systemic inflammatory disorder ${ }^{[1]}$, and generalized edema of extremities is under-represented in the DM literature ${ }^{[2-10]}$. Thus far, there have only been thirteen case reports of DM with severe generalized edema (see Table). Various imaging modalities have been used in the past to delineate the underlying cause of the edema ${ }^{[2-10]}$. Here we have described a case of dermatomyositis and severe edema with abnormal lymphoscintigraphy. Although cutaneous lymphoscintigraphy has been used for many years to evaluate lymphatic drainage patterns, in dermatomyositis, it has been absent from investigators' armamentarium. The aim of this case study and literature review is to gain insight into possible role of lymphoscintigraphy in better delineating pathophysiology and disease progression in such unique presentations.

\section{Case report}

A 57-year-old Hispanic female presented with chief complaint of generalized weakness, four months after progressive proximal muscle weakness and pain in the upper extremities. She had extensive generalized swelling, which was more pronounced in the upper extremities. She developed dysphagia and complained of generalized pain, particularly in the shoulders, arms, jaw and neck. 
Table. Characteristics of patients with edema associated with dermatomyositis

\begin{tabular}{|c|c|c|c|c|c|c|}
\hline Author and Year & Sex & Age & Site of edema & Imaging Modalities & Resolution of edema & Outcome \\
\hline $\begin{array}{l}\text { Gorelik et al. (2001) } \\
\text { (case 1) }\end{array}$ & M & 31 & $\begin{array}{l}\text { Left forearm, extending to } \\
\text { limbs and trunk. }\end{array}$ & $\begin{array}{l}\text { Ultrasonography, CT, } \\
\text { venogram }\end{array}$ & Hydrocortisone & Resolution \\
\hline $\begin{array}{l}\text { Gorelik et al. (2001) } \\
\text { (case 2) }\end{array}$ & M & 63 & Left forearm & $\begin{array}{l}\text { Ultrasonography, CT, } \\
\text { venogram }\end{array}$ & Sodium bicarbonate & Resolution \\
\hline $\begin{array}{l}\text { K. D. Jung et al. } \\
\text { (2011) }\end{array}$ & $\mathrm{F}$ & 52 & Generalized & CT, MRI & $\begin{array}{l}\text { MPL } \\
\text { Cyclosporine }\end{array}$ & Resolution \\
\hline $\begin{array}{l}\text { Y. Chai et al. } \\
\text { (2011) (case 1) }\end{array}$ & M & 62 & Generalized & Ultrasonography & IVIG & Resolution \\
\hline $\begin{array}{l}\text { Y. Chai et al. } \\
\text { (2011) (case 2) }\end{array}$ & $\mathrm{F}$ & 23 & Upper and lower limbs & $\begin{array}{l}\text { Radionuclide bone scan, } \\
\text { Ultrasonography }\end{array}$ & IVIG & Resolution \\
\hline $\begin{array}{l}\text { Y. Chai et al. } \\
\text { (2011) (case 3) }\end{array}$ & $\mathrm{F}$ & 38 & Generalized & None & IVIG & Resolution \\
\hline $\begin{array}{l}\text { Y. Chai et al. } \\
\text { (2011) (case 4) }\end{array}$ & M & 38 & Bilateral upper extremities & Ultrasonography & $\begin{array}{l}\text { MPL } \\
\text { IVIG } \\
\text { Methotrexate }\end{array}$ & Resolution \\
\hline Smyth et al. (2000) & $\mathrm{F}$ & 27 & Forearms & Ultrasonography, MRI & $\begin{array}{l}\text { Prednisolone } \\
\text { Azathioprine }\end{array}$ & Resolution \\
\hline Mroue et al. (2003) & $\mathrm{F}$ & 78 & Upper extremities & $\begin{array}{l}\text { Ultrasonography, } \\
\text { Mammography, CT, } \\
\text { colonoscopy }\end{array}$ & $\begin{array}{l}\text { Prednisone } \\
\text { Methotrexate }\end{array}$ & Death \\
\hline $\begin{array}{l}\text { Werner de Castro et al. } \\
\text { (2006) }\end{array}$ & $\mathrm{M}$ & 40 & $\begin{array}{l}\text { Upper and lower } \\
\text { limbs, trunk }\end{array}$ & $\begin{array}{l}\text { Ultrasonography, } \\
\text { Lymphoscintigraphy, } \\
\text { radionuclide venography }\end{array}$ & No response & Death \\
\hline Ito et al. (2006) & $\mathrm{F}$ & 78 & Upper-lower limbs & $\begin{array}{l}\text { Venogram of arm, } \\
\text { Ultrasonography, CT }\end{array}$ & Prednisolone & Resolution \\
\hline Lee et al. (2008) & $\mathrm{F}$ & 48 & Generalized & $\begin{array}{l}\text { Ultrasonography, MRI, MR } \\
\text { Angiography }\end{array}$ & $\begin{array}{l}\text { MPL } \\
\text { Methotrexate }\end{array}$ & Resolution \\
\hline Haroon et al. (2011) & $\mathrm{F}$ & 61 & Generalized & $\begin{array}{l}\text { Ultrasonography, CT for } \\
\text { pulmonary embolism, PET } \\
\text { scan }\end{array}$ & IVIG & Resolution \\
\hline $\begin{array}{l}\text { Nitsche et al. } \\
\text { (1988) }\end{array}$ & $\mathrm{F}$ & 62 & $\begin{array}{l}\text { Upper limbs, } \\
\text { Trunk }\end{array}$ & None & Prednisone & Resolved \\
\hline This study & $\mathrm{F}$ & 57 & Generalized & $\begin{array}{l}\text { Ultrasonography, } \\
\text { Lymphoscintigraphy }\end{array}$ & MPL & Death \\
\hline
\end{tabular}

On examination, she had a heliotrope rash, and marked erythematous scaly lesions on her chest, right arm and neck. She had tenderness over both shoulders and bilateral pitting edema of the upper and lower extremities. Cardiopulmonary examination was normal with absence of jugular venous distention. Neurological assessment revealed muscle strength of $4 / 5$ in the hip flexors and shoulder abductors, and diminished reflexes throughout.

Patient's vital signs were within normal limits. Pertinent laboratory values include C-reactive protein $4.5 \mathrm{mg} / \mathrm{dl}$, creatine kinase level $353 \mathrm{U} / \mathrm{L}$, aldolase $10.2 \mathrm{U} / \mathrm{L}$, lactate dehydrogenase $265 \mathrm{IU} / \mathrm{L}$, serum albumin $2.8 \mathrm{~g} / \mathrm{dl}$, serum total protein 5.3 $\mathrm{g} / \mathrm{dl}$, aspartate aminotransferase $48 \mathrm{~g} / \mathrm{dl}$, BUN $10 \mathrm{mg} / \mathrm{dl}$ and creatinine $0.4 \mathrm{mg} / \mathrm{dl}$. Autoimmune diseases such as systemic lupus erythematosus, vasculitis, and mixed-connective tissue disease were ruled out by obtaining serum ANA, ANCA, anti-Smith antibody, HLA-B27, RF, and anti-RNP, with negative results. Infectious work-up including HIV and viral hepatitis were negative. Chest radiography and echocardiography were normal, thereby excluding cardiac etiology such as congestive heart failure as the cause for edema. Thyroid diseases were excluded by normal TSH, Free-T4 level. Doppler ultrasonography of the abdomen showed fatty liver, normal kidneys, and negative for deep vein thrombosis of the extremities. Swallow study indicated dysphagia. Lymphoscintigraphy was then performed on both arms. One milli Curie 
(mCi) of 99mTechnetium pertechnetate (99mTc) was injected intradermally in both hands. Dynamic flow images were acquired approximately 10 minutes apart, which initially showed minimal right forearm venous activity progression, and greater visualization of activity in the left forearm. Subsequent delayed images showed progress in the left arm and forearm without axillary visualization, but not in the right forearm (see Figure 1A-1C). Axillary lymph nodes were visualized bilaterally upon delayed imaging acquired at 4.5 hours post-injection (see Figure 1D).

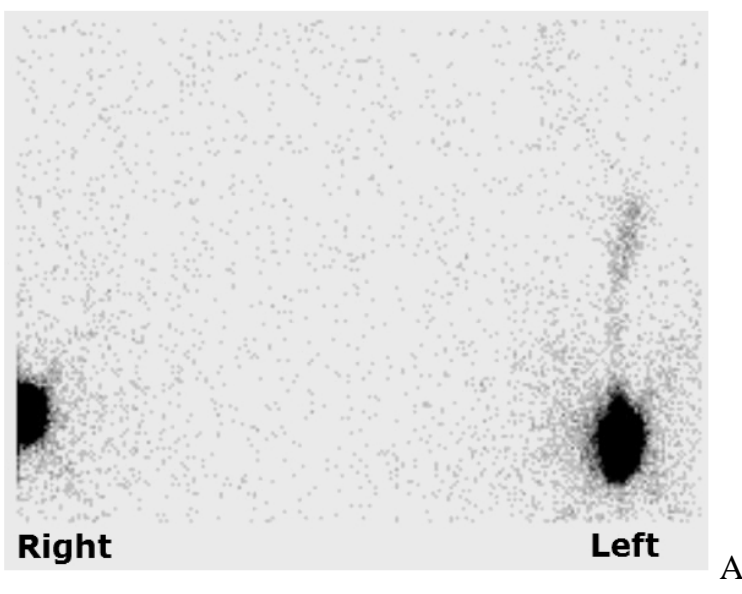

Figure 1A-1C. Dynamic flow images acquired approximately 10 minutes apart after intradermal injection of $1 \mathrm{mC} 99 \mathrm{mTc}$ pertechnetate in the dorsum of both hands. (IS) Injection Site.

A. Minimal right forearm venous activity progression and greater visualization of the venous system in the Left forearm. B. No further progression in the Right arm. Mild progression in the Left forearm and arm. C. No further progression in the Right arm. Greater activity in the Left forearm and arm.

Figure 1D. Delayed 4.5 hour images of the arms and upper torso showing activity in the axillary lymph nodes bilaterally (arrows), exhibiting markedly delayed flow.

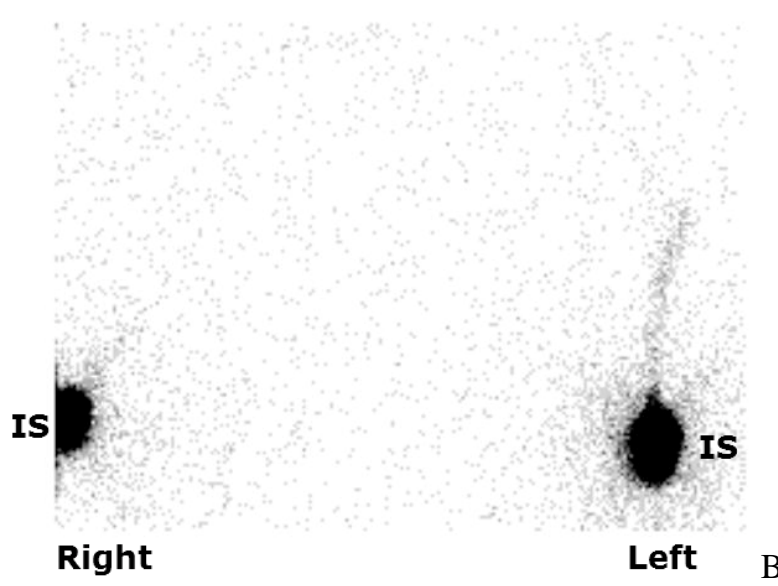

B

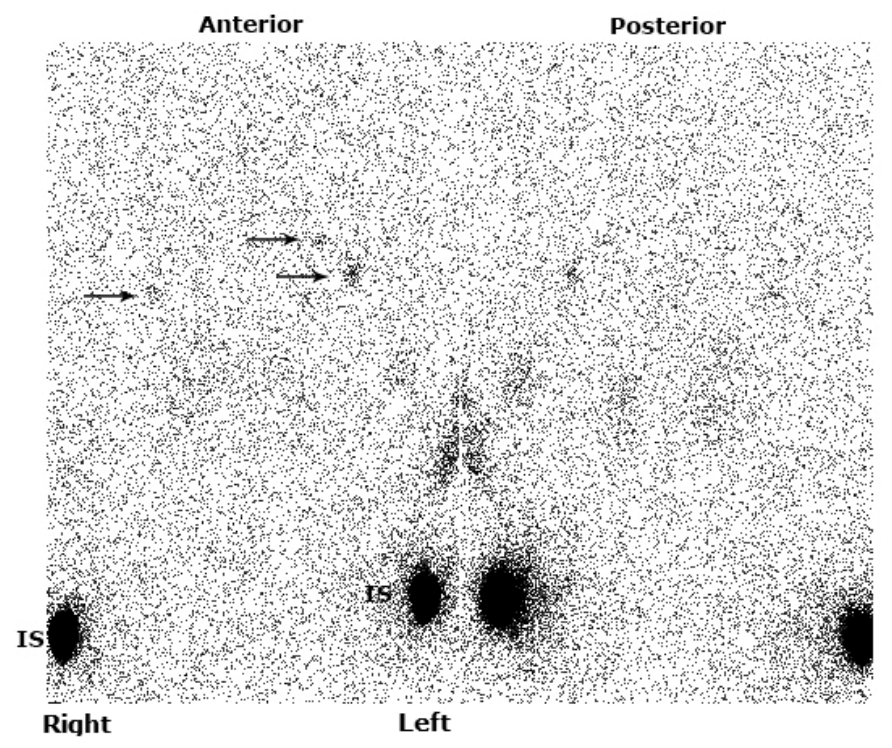


There was evidence of a generalized myopathic process on the electromyogram. Muscle biopsy showed perivascular inflammation and perifasicular atrophy of muscle fiber, which is indicative of dermatomyositis (see Figure 2). Treatment included intravenous methylprednisolone and physical therapy, which resulted in improvement of the edema. The patient was eventually transferred to a skilled nursing facility. As an outpatient, her condition continued to deteriorate and she passed away at an outside hospital due to respiratory insufficiency. No post-mortem examination or autopsy were performed.

Figure 2. Muscle biopsy with H\&E staining, showing perifasicular atrophy of muscle fiber
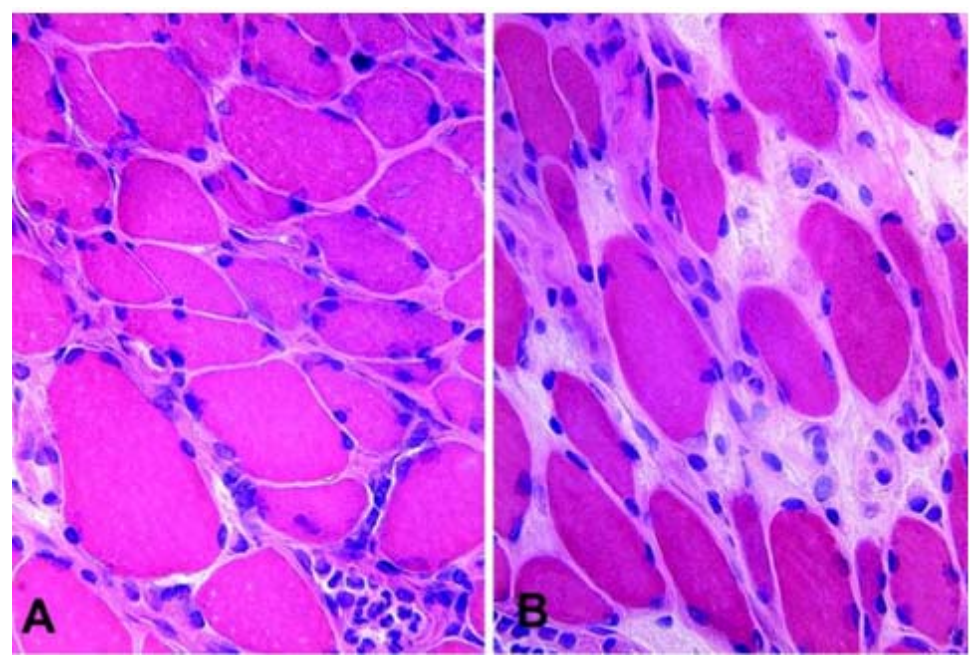

\section{Discussion}

The presence of sentinel diagnostic features such as proximal muscle weakness, skin rash, increased serum muscle enzymes, typical muscle biopsy and EMG findings were consistent with dermatomyositis. Furthermore, the severe edema was attributed to the markedly delayed lymphatic drainage, as identified by the lymphoscintigraphy. A list of thirteen dermatomyositis case reports with edema are presented in Table 1. Including our patient, most of the reported cases were women (10 out of 15), which is consistent with past literature. Greater proportion of women had generalized edema (8 females [53\%], 2 males [13\%]) as opposed to focal edema. Edema was noted in either upper or lower extremities. In eight out of fifteen cases, the edema resolved after administration of steroids only ${ }^{[3,5-9]}$. However, five out of the fifteen cases improved only after the addition of more aggressive treatment ${ }^{[2,4]}$, such as IVIG, possibly suggesting the roles of increased capillary permeability in the pathogenesis of subcutaneous edema. One patient's symptoms resolved without any steroids or immunosuppressants. Werner de Castro et al. used lymphoscintigraphy to assess generalized edema in their patient, but did not report impaired lymphatic flow ${ }^{[10]}$. However, their patient also had underlying thrombosis that could have been the contributory factor for edema. Their patient also shared similar outcomes to our patient, who died of respiratory complications.

The underlying pathogenesis of lymphedema in dermatomyositis patients is unclear, and is often attributed to changes in lymphatic pumping and altered flow during inflammation ${ }^{[11]}$. The significant gender differences in the presentation of lymphedema may allude to underlying differences in mechanisms such as paraneoplastic and inflammatory processes. Despite the normal results of ultrasonography, lymphoscintigraphy demonstrates marked delay of lymphatic flow in both upper extremities. Impedance of lymphatic drainage through inflammatory processes has been implicated in other diseases. Quantitative lymphoscintigraphy has been used to document the severity of lymphedema in other inflammatory conditions such as psoriatic arthritis ${ }^{[12]}$. Stress lymphoscintigraphy can also be performed in cases where lymphatic flow is not visualized on initial dynamic images ${ }^{[13]}$. If the source of edema in dermatomyositis patients has not been clearly identified, other modalities, such as MR lymphangiography may be more appropriate ${ }^{[14]}$. However, if lymphedema is suspected, lymphoscintigraphy represents an accurate imaging modality that is readily available at most institutions ${ }^{[15]}$. 
We suggest that quantitative lymphoscintigraphy could be used to determine the initial severity of lymphedema and monitor response to treatment in the setting of dermatomyositis. Improved quantitative lymphatic flow during aggressive treatments such as IVIG and immunosuppressant may serve as a prognostic tool for overall response to treatment. Prior investigators have suggested that testing of microvascular parameters such as interstitial plasma protein content, colloid osmotic pressure, and interstitial fluid pressure could provide information regarding the pathophysiologic mechanisms of lymphedema in inflammatory conditions, such as dermatomyositis or psoriatic arthritis ${ }^{[16]}$.

In summary, severe edema as a manifestation of lymphatic obstruction is a rare presentation in dermatomyositis, and can provide us with unique information about the underlying pathophysiology of the disease, and lymphoscintigraphy, as a diagnostic tool, could provide possible insight into prognosis and treatment.

\section{References}

[1] Dalakas MC, Hohlfeld R. Polymyositis and dermatomyositis. The Lancet. 2003; 362: 971-82. http://dx.doi.org/10.1016/S0140-6736(03)14368-1

[2] Chai Y, Bertorini TE, Li YD, Mitchell C, Guan H. Limb edema and anasarca associated with severe dermatomyositis: Report of four cases. Neuromuscul Disord. 2011; 21: 439-42. PMid: 21482469. http://dx.doi.org/10.1016/j.nmd.2011.03.003

[3] Gorelik O, Almoznino-Sarafian D, Alon I, et al. Acute inflammatory myopathy with severe subcutaneous edema, a new variant? Report of two cases and review of the literature. Rheumatol Int. 2001; 20: 163-66. PMid: 11411962. http://dx.doi.org/10.1007/s002960000093

[4] Haroon M, Eltahir A, Harney S. Generalized Subcutaneous Edema as a Rare Manifestation of Dermatomyositis: Clinical Lesson From a Rare Feature. J Clin Rheumatol. 2011; 17: 135-7. PMid: 21441819. http://dx.doi.org/10.1097/RHU.0b013e318214f1a9

[5] Ito Y, Kawabata D, Yukawa N, et al. Severe subcutaneous generalized edema in a patient with dermatomyositis. Mod Rheumatol. 2007; 17: 171-3. PMid: 17437177. http://dx.doi.org/10.3109/s10165-006-0560-9

[6] Jung KD, Kim PS, Park HY, et al. Dermatomyositis associated with generalized subcutaneous edema and Evans syndrome. J Am Acad Dermatol. 2011; 66: 144-7. PMid: 22030016. http://dx.doi.org/10.1016/j.jaad.2009.10.035

[7] Lee KH, Lim SR, Kim YJ, et al. Acute dermatomyositis associated with generalized subcutaneous edema. Rheumatol Int. 2008; 28: 797-800. PMid: 18193426. http://dx.doi.org/10.1007/s00296-008-0520-0

[8] Mroue KH, Sharara NH, Rbeiz JG, Arayssi TK. A case of edematous dermatomyositis. J Rheumatol. 2003; 30: 2722-3. PMid: 14719223.

[9] Smyth A, Bell A, Crone M. Acute oedematous dermatomyositis. Ann Rheum Dis. 2000; 59: 574. http://dx.doi.org/10.1136/ard.59.7.574b

[10] Werner de Castro GR, Appenzeller S, Bertolo MB, Costallat LT. Acute dermatomyositis with subcutaneous generalized edema. Clin Rheumatol. 2006; 25: 898-900. PMid: 16308667. http://dx.doi.org/10.1007/s10067-005-0053-9

[11] Von der Weid PY, Muthuchamy M. Regulatory mechanisms in lymphatic vessel contraction under normal and inflammatory conditions. Pathophysiology. 2010; 17: 263-276. PMid: 19945830. http://dx.doi.org/10.1016/j.pathophys.2009.10.005

[12] Dudler J, Gerster JC, So A. Polyarthritis and pitting oedema. Ann Rheum Dis. 1999; 58: 142-7. PMid: 10364910. http://dx.doi.org/10.1136/ard.58.3.142

[13] Scarsbrook A, Ganeshan A, Bradley K. Pearls and pitfalls of radionuclide imaging of the lymphatic system. Part 2: evaluation of extremity lymphoedema. Bri J Radiol. 2007; 80: 219-26. PMid: 16728412. http://dx.doi.org/10.1259/bjr/68256780

[14] Notohamiprodjo M, Weiss M, Baumeister RG, et al. MR Lymphangiography at 3.0 T: Correlation with Lymphoscintigraphy. Radiology. 2012; 264: 78-87. PMid: 22523325. http://dx.doi.org/10.1148/radiol.12110229

[15] Ter SE, Alavi A, Kim CK, Merli G. Lymphoscintigraphy. A reliable test for the diagnosis of lymphedema. Clin Nucl Med. 1993; 18: 646-54. PMid: 8403693. http://dx.doi.org/10.1097/00003072-199308000-00003

[16] Bohm M, Riemann B, Luger T, Bonsmann G. Bilateral upper limb lymphoedema associated with psoriatic arthritis: a case report and review of the literature. Br J Dermatol. 2000; 143(6): 1297-1301. PMid: 11122038.

http://dx.doi.org/10.1046/j.1365-2133.2000.03905.x 